\title{
A Contrastive Stylistic Semantic Study of Imagery in " Badr Alasiab's Your eyes are two palm dates forests " and "Eliot'
}

\author{
Asst.Prof.Hussain Hameed Mayuuf, University of Babylon, College of Education for Human Sciences, \\ Department of English, husm56@gmail.com \\ Masoumah Abathar Witwit, University of Babylon, College of Education for Human Sciences, Department of \\ English,V78bnkbffe@gmail.com
}

\begin{abstract}
The present study is intended to investigate imagery from a semantic and stylistic perspectives in two selected Arabic and English poems. Imagery is the heart of literature that aid readers to be part of the story, the poem, or the play. It supplies us with all details that are related to sight, taste or sensation which in turn arose the emotions of the reader. Without such literary device, Literature would be dull and boring (Di Yanni, 2007, p. 779). The analysis of imagery in the Arabic and the English poems on the stylistic level is based on psychoanalytic approach by Kristeva(1984). The analysis of imagery on semantic levels is limited to the use of lexical items and their significance for imagery in the two selected poems and is based on Leech's (1981) seven types of meaning. The current study is significant, since to the researcher's best knowledge, no other previous study has attempted to analyze imagery in these selected poems from a stylistic semantic perspective. This study sheds light on the notion that stylistics and semantics can work as an integrated field toward a deeper analysis of literary texts.
\end{abstract}

Keywords: Stylistics, semantics, Alfred Tennyson, Badr Alsiab, imagery.

Received: 08.12.2020 $\quad$ Accepted: 13.01.2021 $\quad$ Published: 07.02.2021

\section{Introduction}

Wales (2011) states that imagery from a literary criticism perspective is defined as the common sense that represents a mental picture which is evoked by words. Depending on the type of critic, literary picture could contain figurative language or imagery such as simile and metaphor. The image can arise out of comparing one referent with another like (My love is like a red, red rose, Robert Burns). Dealing with imagery from such perspective is very common in literature. Also, Caroline Spurgeon (1935) divided semantic fields which Shakespeare uses to draw his images.

Literary images whether they are part of prose or poetry are not dealt with as simply decorative but to de familiarize which means to reveal some parts or aspects of an experience in a new and unpredictable way, to reinforce these aspects, setting or characterization (ibid). The present study is intended to analyze and investigate from a contrastive, stylistic, semantic aspects imagery and its types in the two selected English and Arabic poems. The selected English poem is Preludes by T.S Eliot and the Arabic poem is Your eyes are similar of two palm dates forests by Badr Alsiab. The problem of the present study is that to the researcher's best knowledge, no previous study has investigated imagery in the selected English and Arabic poems from a contrastive semantic stylistic perspective. Regarding the aims, 1) analyzing imagery in the Arabic and English poems stylistically, 2) analyzing seven types of meaning that represent imagery in the Arabic and the English poems semantically. 3) comparing the Arabic and English poem regarding the use of imagery in two Arabic and English texts and the purpose behind using it in the two texts. 4) Presenting new semantic fields that contain different types of imagery. The current study hypothesizes the followings: 1) the Arabic and English texts contain seven types of imagery and seven types of meaning. 2) The seven types of imagery that are described by Kristeva(1984) can be applicable in Arabic language literary texts and the seven types of meaning that are developed by Leech (1981) are found in the Arabic language texts. 3) the integration of Semantics and Stylistics leads to new semantic fields.

\section{Stylistics and Semantics}

Wales (2011: 399) defines stylistics simply as " the study of style" and since style can viewed from different aspects, so there are different approaches to stylistics. The variation in the field of stylistics is related to the influence of different linguistic branches. Stylistics is rooted to the earlier studies of Elocutio in Rhetoric. It 
starts with the publication of two-volume treatise on French stylistics by Charles Bally (1909). The real beginning of this field was in 1960 in Britain and the United States which was motivated by post-war developments in descriptive linguistics. Also, Literary Stylistics is defined as dealing with the aesthetic use of language. It deals with both aesthetic canonical literature and with oral narratives, jokes or any type of text. Stylistics participate in the study of literary texts (Kineavy,971). Also, Tariq (2018:1) states that stylistics deals with the study of language and investigating the language of literature and it is one of the approaches to literature. Stylistic is born out of style which is defined as the correspondence between thought and expression and generally. Bary (2011: 207) explain stylistics as moving beyond the sentence grammar to text grammar. It considers how the texts entirely works to achieve its purpose for example to amuse or to suspend or persuade. It investigates and analyze the linguistic features which leads to this end.

Regarding Semantics, Abdurrahman (2019: 1) defines Semantics as" the study of the meaning of words, phrases and sentences. Linguistic semantics deals with the conventional meaning conveyed by the use of words and sentences of a language". Also Bagha(2011) states that semantics investigates the concept of meaning in language. In spite of the fact that semantics investigates meaning in general, it deals mainly with the stable context free meaning which is the opposite of the field of pragmatics which deals with meaning and its use within the context. Semantics deals with the relationships of language to outside world which is called reference and the relationships within language itself like synonym, antonyms.

Considering the relation of stylistics to other sciences, style is a very elusive concept to define and it is related to many perspectives which give rise to different and various definitions. Stylistics is related to all other fields of linguistics as it is evident in the following quotation (" They all assume the existent of some features which are peculiar to style and distinguish it from language. It follows that stylistics is not a mere branch of linguistics but a parallel discipline which investigates the same phenomena from its own point of view" (Ullmann 1973: 41). According to what has been mentioned, stylistics is a multidisciplinary field that is related to all other field of linguistics. Jos and Sorcaru (2008: 1) explain that stylistic effect is mainly produced through different levels of linguistics like phonology, phonetics, syntax, semantics levels. However, Stylistics' closets linguistic friend field is lexicography or semantics. James Joyce's texts is highly rich regarding expressions that has been created by lexical items.

The semantic motivation has the greatest effect on stylistics, since it is related mainly to the imagery of a literary text and its use for manipulation of meaning. The most artful use of semantics in a literary text is found in the use of metaphor, simile and other literary devices in the literary texts. Attempting to analyze the semantic aspect of words in a literary text can reveal the most artistic use made by gifted writers in a literary text. The playing upon meaning and the manipulation of words is highly rich source of stylistic effects can create powerful effects on the reader. It is very clear that Stylistics and Semantics are interdisciplinary and connected to each other (Ullmann 1973: 41).

\section{Poetry and Imagery}

Nursyal (2009: 11) describes poetry as a form of art in that language is used for aesthetic and evocative aims. Also, poetry can be written in individual way or as part of other literary works like a play, novel, and prose or lyrics. Wales (2011) explains that poetic language can be considered as the highest creative forms of discourse which is original in its ideas and creative regarding its form. The notion of deviation is very high in poetry like striking metaphors, unusual collocations, or irregular word order. Creative language can be found in any literary text but in poetry there is unusual use of words, structures, and phrases that are full of connotation. Baldick (2001) states that poetry is regarded as language sung, chanted, spoken, or written. It is based on some pattern that shed light on the relationship between words regarding sounds as well as sense. Mikics (2007) explains that the poet is regarded as maker regarding the imaginative literature.

Wales (2011) defines imagery as being part of the common sense of mental picture. It expresses the idea of a picture that is invoked with words. In imagery such as metaphor and simile, images are evoked through the comparison of one referent with another. Literary images cannot be only decorative and it used for different purposes like de familiarization which means revealing the aspects of the experience in a new way, reinforcing them, and for setting the characterization. Imagery in general deals with the use of language that represents objects, actions, feeling, thoughts, ideas, state of mind and sensory besides extra-sensory experience. Also, it can be said that an image does not always mean a mental picture (Khalid, 2015: 7).

DiYanni $(2007,779)$ explains that imagery is the heart of literature and its basic element. It helps the reader to become immersed in any kind of literary work like poetry, novel, or a play. It supplies the reader with details of sight, sound, taste, smell and touch. These details leads to an emotional response by the reader and 
allows the reader to feel and experience the sittings, the characters, and the actions. The literature without imagry is dry and it becomes hard to reach the feelings of the reader. The most used type of imagry is the visual one because it is the easiest one to articulate. This type of imagery can be very concrete and detailed and it can be used to draw clear images in the head of the reader. The other type of imagry is the sound imagry which can bring life to literature. Also, sounds can arise the emotion of the reader especially the emotions of fear and suspense. The sounds of different voice or dialects can help in gaining the sympathy of the reader. The imagery of taste is a difficult one to convey but it can help in making the reader able to experience the details of the literary work. The other type of imagery is the one of smell which is a very complicated to convey using words and can be hinted by the author (Barry, 2010: 1-9). Finally, when the reader is able to feel, taste, see, hear the details of the literary work, then he or she would be highly affected by the literary work which make it highly appreciated by the reader.

\section{Your Eyes are Two palm dates forests by Badr Alsiab}

Badr Shakir al Sayyab was born in December 24, 1926 and died in 1964. He is an Iraqi Arab poet who was born in Jekor which is a town located south of Basra in Iraq. He was the eldest child in his family and his father was a date grower and a shepherd. He graduated from the Higher Teacher Training College of Bagdad in 1948and later was dismissed of his work for being a member in the communist party. Al Sayyab can be considered as one of the greatest poets in his time. His poetry and experiment helped in changing the form of the modern poetry. The publication of third volume of his work" Song of Rain" in 1960 led to a major change in the contemporary Arabic poetry (Badr Shakir al-Sayyab - Badr Shakir al-Sayyab Biography - Poem Hunter, 2020).

\section{Preludes by T.S. Eliot}

T.S. Eliot is regarded as one of the most important figures in the English Literature. He is the winner of the Nobel prize in Literature in 1948. He is regarded as a great poet, literary critic, dramatist, and editor and publisher. While he was still a college student in 1911 and 1910, he wrote the Love Song J. Alfred Prufrock and other poems that are regarded as part of the greatest poems in the history of the English Literature. His poems are a departure from the 19 century poetry to and within a decade, he wrote the Waste Land and other influential poems in the 20 century. Eliot was a good critic also and from 1912 he wrote one hundred reviews and articles for various periodicals. His first criticism was written a night where he was suffering of his meager salary. He worked first as a teacher then as a bank clerk. Eliot is also considered as an important figure regarding the 20 - century drama. He was mainly interested in drama and his early poems were essentially dramatic and even some of his reviews had been written in a dramatic form (Poetry Foundation T. S. Eliot).

\section{Literature Review}

There are a number of previous studies that have dealt with stylistic or semantic analysis of poetry. Aslam, Aslam, Mukhtar, and Sarfaraz (2014) conduct a study entitled "Stylistics Analysis of the Poem " Bereft" By Robert Frost. The aim of the paper is to analyze Robert Frost's poem "Bereft" stylistically on Graph logical, Grammatical, Syntactical and Phonological levels and analyzing the tropes and schemes used in this poem. This study is significant for analyzing Robert Frost's poetry regarding themes, views and treatment of nature. Mahmood and Jamil (2015). Conducted a stylistic study entitled" A Stylistic Analysis of Holly Thursday I by William Blake". This study aims at analyzing Blake's poem " Holy Thursday I " stylistically based on lexicosyntactic patterns and choices, semantically, grammatically, graph logical and phonological patterns. This study is significant since it analyzes the device of irony in this poem is related to the issue of Cathedral Hypocrisy. This study analyzes the structure and the devices used in this poem and how these devices had been used by the poet to convey his massage of handling of fake ideology forcefully.

Sulaiman(2017) presented a research entitled " Imagery Analysis of Emily Dickenson's Poetry. This study investigates the imagery and its meaning regarding the five poetry of Emily Dickinson 's poetry depending on descriptive qualitative and documentation technique in collecting the data and psychoanalytic approach by Kristeva. The results of this study indicate the existence of sixty-two types of imagery in the poetry of Emily Dickinson which are used to represent the idea of the relationship of humans to God. Kehar(2018) presented a study entitled" Semantic Analysis of Ode to Death Poem". This study analyze this poem Semantically following Gefoery Leech's theory of seven types of meaning to represent the meaning of expressions and devices used in this poem in order to give a clear picture of life and death for the reader. 
Rohani, Arsyad and Diani conducted a study entitled " Semantic Analysis of Figurative Language Expressions in "Feature" Of the Jakarta Posts. This study investigates the kinds of figurative expressions found in " feature" of The Jakarta Post's December editions. This study is based descriptive qualitative content analysis. The most dominant device used in these posts was simile and the most used meaning regarding seven types of meaning is the conceptual meaning. It has been proved by this study that the use of simile and the conceptual meaning the Jakarta posts make them more effective for the reader. The study recommends the use of such devices in the teaching material for more effective learning.

None of the previous studies to the researcher's best knowledge has tackled a stylistic semantic study for analyzing imagery in two selected Arabic and English poems. The present study fills this gap by dealing with integration of both Semantics and Stylistics as fields to analyze literary genre in different language. The presents study suggests the notion of stylistic semantic field for deeper analyses of literary texts and the devices used in these type of texts especially poetry.

\section{Methodology}

The method of the current study is a qualitative one. The model of the present study is an eclectic one that consists of Leech's (1981) seven types of meaning and seven types of imagery by Kristeva(1984). The data under study is the Arabic Poem Two Palm Dates and the English Poem Summer night. The Arabic poem's analysis is presented with translation by Khaloud Al-Muttalib. The model of the present study is the following:

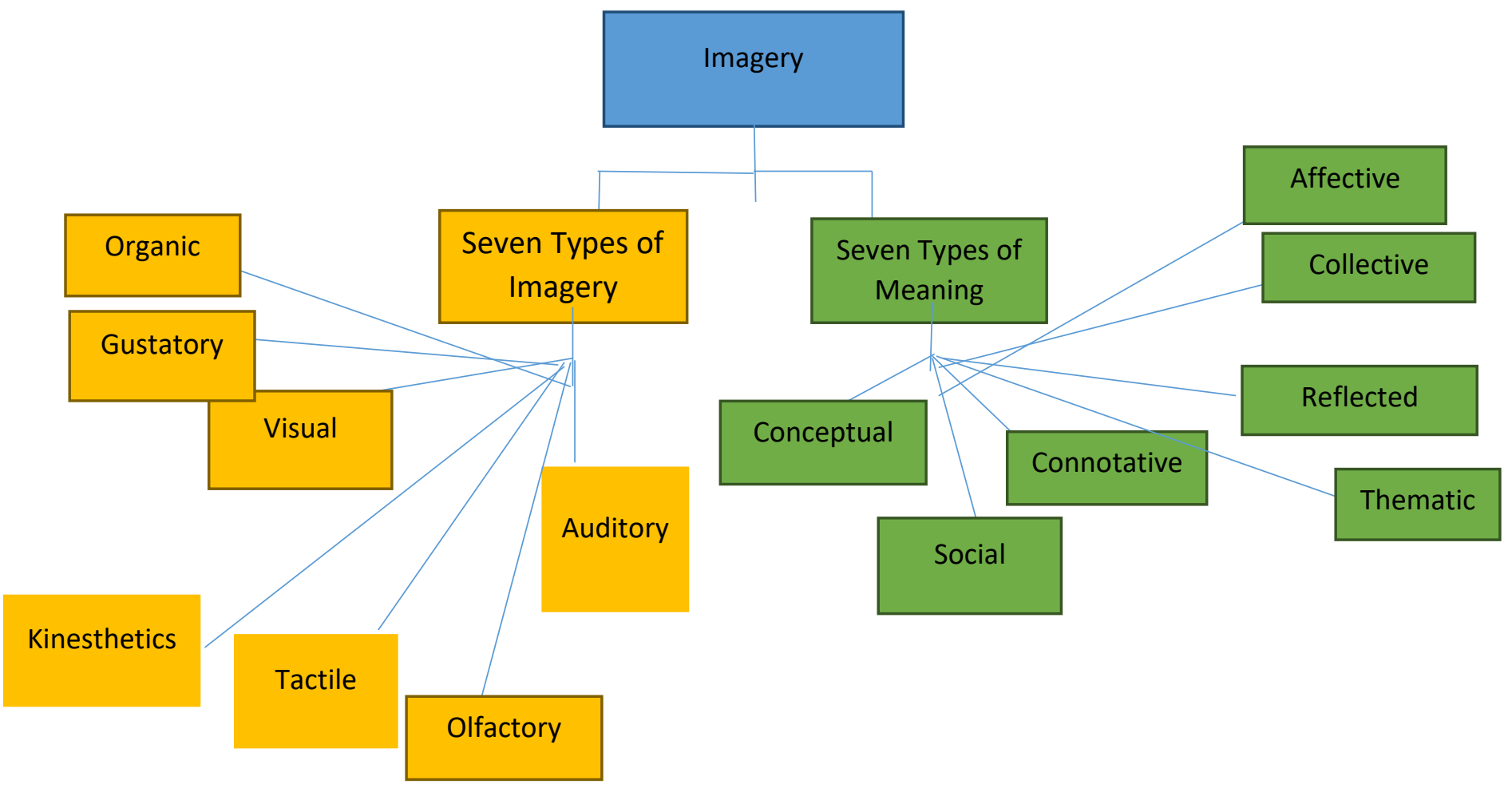

Figure number (1)

\section{Data Analysis and Results}

In this section, the device of imagery will be analyzed in the Arabic and the English poem.

\section{Badr Alasiab's Your eyes are two palm dates forests}

The imagery in this poem will be analyzed stylistically first using by Kristeva 's (1984) seven types of imagery that are organic, gustatory, visual, auditory, tactile, olfactory, and Kinesthetics. Then, the imagery in this poem will be analyzed using Leech's (1981) seven types of meaning.

\section{The Stylistic Analysis \\ A- Auditory}


This type of imagery is related to sounds like " buzzling, tinkling,

chiming, and many words that are related to sounds Baldick (2001).

و كركر الاطفال في عر ائش الكروم

And the children burst into laughter in the vineyard bowers

تئثائب المساء و الغيوم ما تز ال

The evening yawned and the clouds were still

كان طفلا بات يهذي قبل ان ينام

As if a child, before sleeping, was raving about his mother

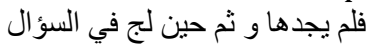

he woke up and did not find her

And when he kept asking about her

و ان تهامس الرفاق انها هناك

Yet his companions whisper that she is there

و يلعن المياه و القدر

Cursing the water and fate

و ينثر الغناء حيث يافل القمر

Scattering songs as the moon sets

اكاد اسمع العراق يذخر الرعود

I almost hear Iraq massing thunder

اكاد اسمع النخيل يشرب المطر

I almost hear the palm trees drinking the rain

و اسمع القرى تئن و المهاجرين

Hear the villagers groan and the immigrants

مطر مطر مطر

Rain, Rain, Rain

و يهطل المطر

And the rain would pour down

و كيف تتشج المر ازيب اذا انهر ؟

And how gutters sob when it pours down?

The poet uses auditory imagery for several reasons, to express his feelings and his desire to cry, to express the suffrage of the Iraqi people by focusing on villagers groaning, to describe the sound of the rain while falling and beauty of Iraqi palm trees. To describe the fisher' s song and his suffering, to reflect the image of the child who lost his mother, to add the beautiful image of the children laughter, and finally to describe the beauty of Iraq' nature and weather.

\section{B- Visual}

Baldick (2001) states that the visual imagery is a type of imagery which is related only to visual imagination. This type of imagery is often found in poetry because the poet presents his words as something that can be seen.

ع إناك غابتا نخيل ساعة السحر

Your eyes are two palm tree forests at early dawn

او شرفتان رح يناى عنهما القمر

Or two verandas from which the moonlight recedes

عيناك حين تبسمان تورق الكروم

When your eyes smile, the vines put forth their leaves

و ترقص الاضواء كالاقمار في نهر

And the lights dance like moons in a river

يرجه المجداف و هنا ساعة السحر

Rippled by an oar at an early down

كانما تتبض في غوريهما النجوم

As if the stars were pulsating in their depth

و تغرقان في ضباب من اسى شفيف

And they drown in a mist of sheer sorrow

كان اقواس السحاب تشرب الغيوم

As if arches of mist were drinking the clouds

و قطرة فقطرة تذوب في المطر 
Drop by drop dissolved in the rain

كان صيادا حزينا يجمع الثباك

As if a sad fisherman was gathering nets and

و كيف تنشج المرازيب اذا انهمر ؟

And how gutters sob when it pours down?

بلا انتهاء - كالدم المراق , كالجياع

Endlessly like bloodshed, the hungry, love, children and the

كالحب , كالاطفال , كالموتى - هو المطر

love, children and the

dead -It is the rain

في كل قطرة من المطر

In every drop of rain

حمر اء او صفر اء من اجنة الزهر

Red or yellow buds of flowers

و كل دمع من الجياع و العراء

Every tear shed by the hungry and naked

و كل قطرة نراق من دم العبيد

And every drop of slaves' blood shed

او حلمة توردت على فم الوليد

Or a nipple becomes rosy in an infant's mouth

سيعشب العراق بالمطر

Iraq will become green"

و ينثر الخليج من هباته الكثار

The gulf scatters its plentiful gifts

على الرمال , رغوة الاجاج و المحار

On the sand: a lather of salty water and shells

و ما تبقى من عظام بائس غريق

And the remains of the drowned forlorn immigrant still

و في العراق الف افعى نشرب الرحيق

In Iraq a thousand serpents drink

من ز هرة يربها الفرات بالندى

The nectar from a flower, the Euphrates has nurtured with

في كل قطرة من المطر

In every drop of rain

حمر اء او صفر اء من اجنة الزهر

Red or yellow buds of flowers

The visual imagery is the most used one by the poet in his poem. He uses them for many aims or reasons that are: to describe the beauty of Iraq's nature by presenting different colors of flowers, to reflect the idea that Iraq has many enemies by the use of the metaphor snake, to describe the suffrage of the Iraqi people by presenting the image of a drowned person, the image of an Iraqi people's tear or blood and starvation, to describe the beauty of the Iraqi 's coast, to describe the beauty of his eyes' beloved by comparing them metaphorically to palm trees at the dawn time and to a verandas covered by the moons' light and the effect of his beloved eyes extend to influencing the trees and their leaves, the lighting dance in the river. He also describes the beauty of his beloved by comparing it the river that is personified as person and have stars that are beating inside it, to describe the image of fisherman, and the image of a the rain falling on the gutter and its sobbing like a human being (Alakrash et.al.2020, Bustan \&Alakrash 2020, Elaf \& Hussien 2020, Bustan \& Alakrash 2020).

\section{c- Tactile}

This type of imagery is related to temperature and tactile senses like coldness and warmness. It is related to hot and cold or touch sense (ibid).

دف الثتاء فيه و ارتعاثشة الخريف

Containing the warmth of winter and the quiver of Autumn

The poet uses the tactile imagery to describe the beauty of his beloved by comparing it to the the warmth of summer and the coldness of the winter.

\section{D-Olfactory}


Olfactory imagery is related to olfactory or to smelling sense like " fragrant" or any type of unpleasant smell (ibid). There is no olfactory imagery in this poem.

\section{E- Gustatory}

This type of imagery is related to taste as in sweet or briny and anything related to flavor in the literary work (ibid).

$$
\text { في جانب التل تنام نومة اللحود }
$$

Lying dead by the side of the hill

تسف من تر ابها و تشرف المطر

Eating soil and drinking rain

اكاد اسمع النخيل يشرب المطر

I almost hear the palm trees drinking the rain

من المهاجرين ظل يشرب الردي

immigrant still drinking death

The gustatory imagery is used by the poet in these lines to influence the reader by the image of the dead mother who is drinking rain and eating soil while her son is still waiting for her. It is also used by the poet to describe the beauty of the palm trees under the rain and finally to describe the suffering of Iraqi immigrants.

\section{F- Organic}

This type of imagery is related to internal sensation of the human body like hunger, thirst, and pain (ibid).

$$
\text { و في العراق جوع }
$$

And there is hunger in Iraq

كل عام حين يعشف الثرى نجوع

And every year, when soil becomes green

We starve

ما مر عام و العراق ليس فيه جوع

Not a year passed and Iraq has not suffered starvation

This type of imagery is used by the poet to describe the suffering of the Iraqi people.

\section{G- Kinesthetic}

This type of imagery is expresses a movement or tension in the muscles or joints (ibid).

دفء الثتاء و ارتعانثة الخريف

Containing the warmth of winter and the quiver of Autumn

فتستفيق ملء روحي رعشة البكاء

A sobbing flares up to shiver in my soul

This type of imagery is used by the poet to describe his own physical condition. The influence of his beloved is like the coldness feeling in the winter and the warmth feeling in the summer. It is also used to describe the physical condition of the poet before crying.

\section{1-8-1-2 The Semantic Analysis}

\section{A-The Conceptual Meaning}

This meaning is also called cognitive meaning and is regarded as the central aspect of Linguistic communication. The features of this type of meaning are limited and close ended. The conceptual meaning of the word is fixed and unchangeable (Dwiyanti, 2016). In Arabic, the conceptual meaning is called ( مرحلة الدلالة as was described by Muhammad Baghir As-Sadir in his book (Darus fi Ilm ul Usul).

اصيح بالخليج يا خليج

I call out on the gulf "O gulf

و في العراق جوع

And there is hunger in Iraq

و ينثر الغلال فيه موسم الحصاد

The harvest scatters the corn inside it

التثبع الغربان و الجر اد

The locusts and crows may eat their fill

و تطحن الثوان و الحجر

Granaries and stones grind on and on

رحى تدور في الحقول ... حولها بشر

Mills turn in the fields surrounded by humans 
و منذ ان كنا صغار ا , كانت السماء

Since we were children, the sky would be clouded

تغيم في الشتاء

in winter

و يهطل المطر

And the rain pours down

و كل عام - حين يعشب الثرى - نجوع

And every year, when soil becomes green

We starve

ما مر عام و العراق ليس فيه جوع

Not a year passed and Iraq has not suffered starvation

في كل قطرة من المطر

In every drop of rain

حمر اء او صفر اء من اجنة الزهر

Red or yellow buds of flowers

و كل دمة من الجياع و العراة

Every tear shed by the hungry and naked

و كل قطرة نر اق من دم العبيد

And every drop of slaves' blood shed

فهي ابتسام في انتظار مبسم جديد

Is a smile awaiting a new mouth

او حلمة توردت على فم الوليد

Or a nipple becomes rosy in an infant's mouth

و يهطل المطر

And the rain pours down

The conceptual meaning is used by the poet in these lines for describing a very realistic image of Iraqi people's suffering and their starvation in the harvest seasons especially. The poet through the conceptual meaning present allegorically that Iraq resources are deprived and taken for other countries and political figures while Iraqi people are starving till death. It is also used for describing the blood and the tears of those people but in spite of all of this suffering, there is a hope of the better future which is reflected in the image of the child who is feeding from his mother's breast. The image of the child reflects the new generation who can lead the change.

\section{B- The Social Meaning}

This type of meaning express social circumstances through the use of a piece of language like pronunciation variation, a word, phrase or a sentence. Social meaning is indicated through understanding of different dimensions at the level of style which are used for language variation. This variation can be social or regional variation or style variation like formal, informal, colloquial or slang. In this regard, the social meaning is different from the conceptual meaning and it is expressed through different illocutionary forces (Umagandhi and Vinothini, 2017: 72).

اصيح بالخليج : يا خليج

I call on the gulf": 0 gulf

يا واهب الؤلؤ , و المحار و الردي

0 giver of pearls, shells and death

اكاد اسمع العر اق يذخر الرعود

I almost hear Iraq massing thunder

اكاد اسمع النخيل يشرب المطر

I almost hear the palm trees drinking the rain

عو اصف الخليج و الرعود منشدين

The gulf storms and thunders singing

و في العراق جوع

And there is hunger in Iraq

سيعشب العراق بالمطر

Iraq will become green" 
The social meaning is used by the poet to reflect his nationality as an Iraqi citizen. These lines reflect the poet's homeland in the south of Iraq near the coast and his experience regarding the coast's pearls, shell and death. It also reflects his awareness of Iraqi people suffrage and its social and national problems.

\section{D- Affective Meaning}

It is the aspect of meaning which is concerned with expressing personal feelings and attitudes of the speaker and the listener (Umagandhi and Vinothini , 2017: 72).

فتستفيق مل روحي رعشة البكاء

A sobbing flares up to shiver in my soul and

اتعلمين اي حزن يبعث المطر ؟

Do you know what sorrows the rain can prompt?

و كيف يشعر الوحيد فيه بالضياع ؟

Do you know how lost a lonely person feels in the rain?

و كم ذرفنا ليلة الرحيل من دموع

How many tears we shed when the night of departing arrived

The affective meaning is used by the poet to describe his own mental and psychological state and his loneliness. He uses the affective meaning to describe his spiritual condition before crying, to explain his sadness and loneliness when it rains, and finally to describe his situation when he parted those whom he loved.

\section{E- Connotative Meaning}

Leech (1981) defines connotative meaning as the communicative value that an expression contains by referring to something over the conceptual meaning. It is related mainly to the real world experiences that are expressed by linguistic expressions. It is unstable and varied according the culture. This type of meaning is called ( المعنى المجازي) as was stated by As-Sadr (1990).

عيناك غابتا نخيل ساعة السحر

Your eyes are two palm tree forests at early dawn

او شرفتان راح يناى عنهما القمر

Or two verandas from which the moonlight recedes

عيناك حين تبسمان تورق الكروم

When your eyes smile, the vines put forth their leaves

و ترقص الاضواء . . كالاقمار في نهر

And the lights dance like moons in a river

كانما تتبض في غوريهما , النجوم

As if the stars were pulsating in their depth

و تغرقان في ضباب من اسى شفيف

And they drown in a mist of sheer sorrow

كالبحر سرح اليدين فوقه المساء ,

Like the sea stroked by the hands of the evening

كنشوة الطفل اذا خاف من القمر !

An ecstasy of a child scared by the moon

كان اقواس السحاب تثرب الغيوم

As if arches of mist were drinking the clouds

و كركر الاطفال في عر ائش الكروم

And the children burst into laughter in the vineyard bowers

و دغدغت صمت العصافير على الثجر

The rain song tickled the silence of the sparrows on trees

تثاءب المساء, و الغيوم ما تز ال

The evening yawned and the clouds were still

تسح ما تسح من دمو عها الثقال

and the clouds were still Pouring their heavy tears

بلا انتهاء - كالدم المراق , كالجياع ,

Endlessly like bloodshed, the hungry, love, children and the

كالحب, كالاطفال , كالموتى _هو المطر !

love, children and the 
dead It is the rain

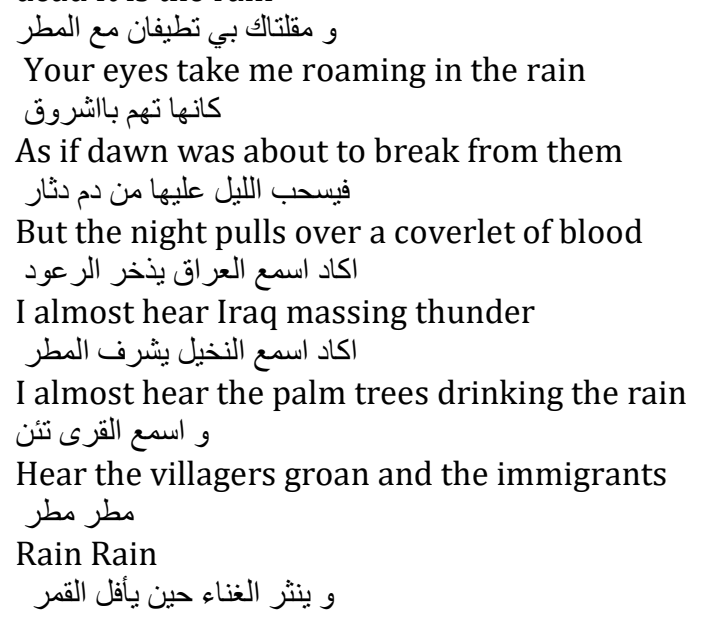

The connotative meaning is used heavily by the poet for a number of aims: for comparing his beloved using metaphor and visual images for a number of aims : for comparing his beloved metaphorically to the woods at the time of down, comparing her to verandas covered by the moon's light, the beauty of these eyes effect the vines and the dancing light on the water of the river, comparing the beauty of his beloved eyes to different images like a child scared from the room, the mist, and the children laughter, comparing the rain to love, children, and blood. Besides being associated to the visual imagery, the connotative meaning is related to auditory imagery like the sounds of the thunder, the sound of the palm trees when it rains on them, the sounds groaning of villagers, the song of a fisherman and the sound of the rain.

\section{F- Reflected Meaning}

This type of meaning can be expressed through the relationship between two words or connection on the lexical level. It is the meaning that arise when one word has a number of meanings and the sense of one word forms the response to another sense of the same word (Umagandhi and Vinothini, 2017: 72).

كانما تنبض في غوريها النجوم

As if the stars were pulsating in their depth

كنشوة الطفل اذا خاف من القمر !

An ecstasy of a child scared by the moon

و كركر الاطفال في عرائ الكروم

And the children burst into laughter in the vineyard bowers

تسف من ترابها و تشرب المطر ,

Eating soil and drinking rain

و كيف تتشج المرازيب اذا انهر

And how gutters sob when it pours down?

و مقلناك بي تطيفان مع المطر

Your eyes take me roaming in the rain

The poet uses the reflected meaning for describing the beauty and the depth of his beloved eyes by using the word " عمق "which means depth to compare the depth of her eyes to the depth of the river that is occupied by stars. It is also used by the poet to describe the poet's condition using the word " ecstasy" " to show contrasting feelings of happiness that is similar to child' fearing of the moon and sadness that is combined by sobbing of tears and crying. The word " كركر " "laughter" is used by the poet to describe the sounds of the child's laughter when the rain falls. The word " كركف" "نat" has many meaning but her is used to describe the state of the buried mother that feeds on soil of her grave. The description of the dead mother can refer to poet himself who has lost his mother when he was a child. The poet uses "تنشج" " sob" to personify the gutters as real humans who sob when they cry heavily. The word "تطيفان" " roam" is used to describe impact of the poet's beloved eyes to the extent that metaphorically these eyes roam with the poet in the rain.

\section{I - Collective Meaning}


This type of meaning deals with connections or associations that a word gain or acquire by the meaning of the words which tends to occur in the same environment (Leech 1981:17).

دفء الثتاء و ارتعاشة الخريف

Containing the warmth of winter and the quiver of Autumn

و الموت, الميلاد ,و الظلام, ,و الضياء

And death and birth, darkness and light

كان اقو اس السحاب تشرب الغيوم

As if arches of mist were drinking the clouds

و دغدغت صمت العصافير على الثجر

The rain song tickled the silence of the sparrows on trees

كأن صيادا حزينا يجمع الشباك

As if a sad fisherman was gathering nets

اصيح بالظليج " با خليج

I call out on the gulf " 0 gulf

يا واهب الؤلؤُ , و المحار و الردي !

O bestower of pearls, shells and death"

و ينثر الخليج من هباته الكثار

The gulf scatters its plentiful gifts

على الرمال : رغوة الاجاج و المحار

On the sand: a lather of salty water and shells

The collective meaning is used by the poet to describe a number of meanings or connotations in the same line.

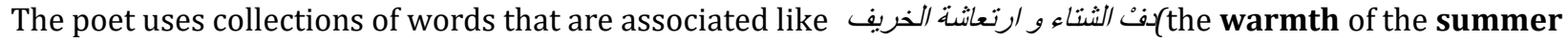
and coldness of the winter) to describe the effect of rain and his beloved eyes on him. The poet also uses collective meaning كان اقواس السحاب تشرب الغيوم to personify mists as humans or animates who drinks the water of the clouds. He also uses و دغدغت صدت العصافير على الثجر الغرب The rain song tickled the silence of the sparrows on trees to describe the impact of the rain on nature.

\section{J-Thematic Meaning}

This type of meaning is expressed or communicated by the way related to the speaker's or writer's organization of the message regarding order, focus, and emphasis (Leech, 1981: 19).

و عبر امو اج الخليج تمسح البروق

I hear the echo Resounding in the gulf

ساو احل العر اق بالنجوم و المحار

The Iraqi shores with stars and shells

و كل عام - حين يعشب الثرى - نجوع

And every year, when soil becomes green- We starve

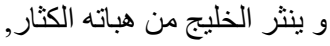

The gulf scatters its plentiful gifts

على الرمال : رغوة الاجاج , و المحار

On the sand: a lather of salty water and shells

The poet uses thematic meaning to describe the beauty of the gulf and the sands' shore with shells and stars , and finally to describe the Iraqi people's suffering and their starvation in the harvest season.

\section{Preludes by T.S. Eliot : The Stylistic Analysis}

A- Visual

The evening settles down

The burnt-out ends of smoky days

And now a gusty shower wraps

The grimy scraps

Of withered leaves about your feet

And newspapers from vacant lots

And then the lightning of the lamps

To early coffee-stands.

With the other masquerades

One think of all the hands 
That are raising dingy shades

In a thousand furnished rooms.

You tossed a blanket from the bed,

You lay upon your back, and waited

You dozed, and watched the night reveling

The thousand sordid images

They flickered against the ceiling.

And the light crept up between the shutters

You had such a vision of the street

Sitting along the bed's edge, where

You curled the papers from your hair

Or clasped the yellow soles of feet

In the palms of both soiled hands

His soul stretched tight across the skies

That fade behind a city block

Or trampled by insistent feet

And short square fingers stuffing pipes

And evening newspapers and eyes

Assured of certain certainties

The conscience of blackened street

The world revolves like ancient women

Gathering fuel in vacant lots

The poet uses visual imagery to describe the evening in the city and the bad smell that is scattered in the streets. The poet uses metaphor to compare the end of the day in the city to the end of the cigarette. Then, the image of the heavy raining in the streets. He describes the image of newspaper pieces in the street under people's feet. The poet describes people who came back from their works in the city with the picture of lightening the lamps inside their apartments. He also visualizes the image of people in the morning standing in long stands for drinking coffee. The poet describes people in their boring monotonous life using metaphor by comparing them to people who are wearing masks in a ball. He visualizes people as being hands or parts of the body rather than complete human beings. Then the poet moves to the image of people in their apartments in the nights and moves to picture a person who throw blanket on himself and watched the things around him. Then, the poet visualizes the image of the morning, and a women sitting on a bed. Then, the poet visualizes the image of a spirit that is lost in the street and ignored by people. This image refers metaphorically and allegorically to the soul of Christ or people's conscious that is lost from them. The final image is for a woman who is gathering fuel from an empty place. The women in the last image refers to birth and the whole image refers to cycle of life that is moving the same way.

\section{B- Auditory}

The showers beat

On Broken blinds and chimney -pots

A Lonely cab-horse steams and stamps.

From the sawdust-trampled street

With all its muddy feet and press

And you heard the sparrows in the gutters,

The poet uses auditory images for a number of reasons: to describe the sound of the rain and its beating on people who are described as both broken and blinds and on the beating of the rain on the chimneys. He uses this imagery to describe the sound of the horse under the rain. It is also used to describe the sounds of the sparrows in the morning.

\section{C- Tactile}

There is no tactile imagery in this poem

D- Olfactory

With smell of steaks in passageways

The morning comes to consciousness 
Offaint stale smells of beer

The poet uses olfactory imagery to describe the disgusting smell that spread in the streets in the early morning. This image refers to the polluted air of the city.

E- Gustatory

There is no gustatory imagery in this poem.

F- Organic

There is no organic imagery in this poem.

G- Kinesthetic

Wipe your hand across your mouth, and laugh

This image is used to describe the image of a person who is wiping his hand and the conclusion of the poem that life in the city is moving like an endless cycle that repeats itself every day in the same way and the same boring life.

\section{The Semantic Analysis: The Conceptual Meaning}

Six o'clock

And now a gusty shower wraps

The grimy scraps

of withered leaves about your feet

The showers beat

On broken blinds and chimney - pots

And at the corner of the street

A lonely cab-horse steams and stamps

And then the lightening of the lamps

From the sawdust-trampled street

With all its muddy feet that press

To early coffee- stands

That time resumes

One thinks all the hands

The conceptual meaning is related mainly to the visual and auditory imagery. It is firstly used to describe the time of the night and the sound of the heavy rain. Then it moves to describe the image of the newspaper scraps on the street. It also describes the sound and the image of the rain falling on the streets and chimney -pots and the image of horse standing in the rain. Then it moves to the image when people go back to their houses after their work and lightening the lamps. Then the image of morning reflected on muddy and dirty streets and people in their works who are drinking coffee. The conceptual meaning is used in this poem to describe the dull life of people who are living in the city and that time is like a cycle that repeats every detail in a monotonous way.

A- The Social Meaning

The entire poem is designed to express social meaning. It expresses the dull life of the city and its boring routine.

\section{B- Affective Meaning}

The winter evening settles down

This line has a romantic tone which expresses those who are coming back from the works at the evening. This line contains affective meaning. It expresses the loneliness and tiredness of people who are coming back from their work in the evening.

And now a gusty shower of wraps

The sower beats

The rain is personified her as an angry person who is expressing his feeling violently.

The morning comes to consciousness

Of faint stale smell of beer

From the sawdust- tramples street

With all its muddy feet that press

To early coffee -stands 
These lines express affective meaning in that the change from evening to morning and its consciousness reflects the speakers' feeling as being alert and awaken after being in a state of consciousness of the previous night.

To early coffee -stands

This line expresses the affective meaning since it reflects the frantic and hasty life of people in the city who are drinking their coffees standing on their feet.

You tossed a blanket from the bed,

You lay upon your back, and waited;

You dozed, and watched the night revealing

The thousand sordid images

Of which your soul was constituted

Sitting along the bed's edge, where

You curled the papers from your hair,

These lines express affective meaning since it reflects the speaker who sits alone in a room feeling lonely and in the night and moving from consciousness to sub consciousness of the night.

The conscience of a blackened street

Impatient to assume the world

These lines contain affective meaning since it expresses allegorically the Christ 'soul who is suffering and also the conscience of people who leave in the city that is also suffering from this boring, monotonous and tiresome life.

I am moved by fancies that are curled

Around these images and cling:

The notion of some infinitely gentle

Infinitely suffering thing.

These lines carry affective meaning, since the speaker is moved and affected by the boring life of the city and its miserable inhabitants. Also he is affected by the Christ soul and people's conscience who is ignored by people.

C- Connotative Meaning

"The burnt-out ends of smoky days"

This line contains connotative meaning, the poet here compares by the use of metaphor the time of the day to the ashes of the cigarette.

"With the other masquerades"

People are acting as they are living a meaningful life.

The worlds revolve like ancient women/ Gathering fuel in vacant lots."

These line contains connotative meaning because the poet uses metaphor in this line to refer to the cycle of life that moves without end. Women her refers to the cycle of life since they give birth. The last image in this line have paradox in that women are gathering fuel to make fire from an empty space. This conative meaning reflects the idea that there is nothing that is lively in this world, yet people continue to live in it.

The morning comes to consciousness

Offaint stale smells of beer

The winter evening settles down

With smell steaks in passageways

These lines contain connotative meaning since the morning and the winter are personified as real human beings.

\section{F- Reflected Meaning}

The winter evening settles down

The phrasal verb settles down is used connotatively to personify the winter as a real human being.

On Broken blinds and chimney-pots

The words broken and blinds here are used connotatively to refer to the people of the city who are living blindly and described as being broken. 
The Conscience of a blackened street

The word lexical item is used connotatively to personify the street and to refer allegorically to Christ or the conscience of the people's city.

\section{I - Collective Meaning \\ The burnt -out ends of smoky days \\ And now a gusty shower wraps \\ And then the lighting of the lamps \\ From the sawdust - trampled street \\ With all its muddy feet that press \\ You tossed a blanked from the bed \\ They flickered against the ceiling}

These lines contain collective meaning, since the words that they carry associative meaning like burnt out ends and smoky that both refer to cigarette, gusty shower and wraps that both refer to the rain, the lightening and the lamps that both refer to light, the sawdust, muddy that refer to street, blanked and the bad, and finally flickering and ceiling.

\section{J-Thematic Meaning}

The thousand sordid images

Of which your soul was constituted

The fronting of the sordid images was done by the poet to shed light on the desperate human soul in the monotonous life of the city.

The consciousness of a blackened street

Impatient to assume the world

The poet here shed light on consciousness and impatient to refer to the religious image of Christ and people's lost conscious.

\section{The Comparison between the Arabic and English Texts}

Imagery and seven types of meaning have been used for different aims in the Arabic Poem Your eyes are two palm dates forests and the English poem Prelude. In the Arabic poem, Alsiab uses visual, auditory imagery and conceptual meaning for describing the beauty of his beloved and his country Iraq. He uses affective meaning with kinesthetic and tactile imagery to describe his own feelings of loneliness and his sobbing. The social meaning and conceptual imagery are used for describing the social issues and problems. Regarding Prelude, Eliot uses conceptual meaning with visual and auditory to describe the dullness of the life in the city. The affective meaning with kinesthetic imagery is used to describe the feelings of those who live in the city. The social meaning with visual imagery is used to describe the social condition of those who live this boring life in the city.

\section{Conclusion}

The stylistic semantic investigation of imagery in the two poems leads to the following conclusions. The seven types of imagery and meaning are found in the English and the Arabic poem with varying degrees and for different purposes. The seven types of meaning that are proposed by Leech (1981) and seven types of meaning imagery proposed by Kristeva(1984) are found in the Arabic poem and they are found in Arabic language which needs further research and investigation in the Arabic Language The integration of stylistic and semantic fields in the present study leads to the integration between imagery as a stylistic study and seven types of meaning as a semantic study leads to different new semantic fields. The connotative meaning contains as a semantic field the visual and auditory imagery. The conceptual meaning contains as a semantic field the realistic visual and auditory images. The affective meaning as a semantic field contains kinesthetic and tactile imagery. The social meaning contains the visual imagery this is realistic and used to present realistic social affairs. Finally, the integration between Semantics and Stylistics can leads to very fruitful results and new dimensions' in the investigation of literary genre especially poetry.

\section{Bibliography}

Abdurrahman, I .(2019). Semantics. College of Education for Women / Tikrit University 
Alakrash, HM, Razak, NA, \& Bustan, ES (2020). The Effectiveness Of Employing Telegram Application In Teaching Vocabulary: A Quasai Experimental Study. Multicultural Education, 6(1).

Al-Muttalib, K. (2012). THE RAIN SONG by Badr Shakir Al-Sayyab translated from Arabic by Khaloud AlMuttalib.Knot

https://middleeasternliteraturejournal.wordpress.com/author/middleeasternlit1970/

Magazine.

Aslam, S. Aslam, B. Mukhtar, P. Sarfaraz, A. (2014). Stylistic Analysis of the Poem "Bereft" by Robert Frost. European Journal of Research and Reflection in Arts and Humanities. Vol. 2 No. 1, 2014

Bagah , S, k. (2011). A Short Introduction to Semantics. Journal of Language Teaching and Research, Vol. 2, No. 6, pp. 1411-1419, November 2011

Baldick, C. (2001). Oxford Concise Dictionary of Literary Terms. New York, NY: Oxford University Press.

Baldick, C. (2001). Oxford Concise Dictionary of Literary Terms. New York, NY: Oxford University Press.

Bustan, E.S, Alakrash, H. M. (2020). Critical Discourse Analysis of Donald Trump's Tweets Addressing the Middle Eastern Countries.International Journal of Future Generation Communication and Networking,13(2), 26-38.

Bustan, E.S., Alakrash, H. M. (2020). Gender Analysis Amongst Male and Female Malaysian Travelling Bloggers. International Journal of Academic Research in Business and Social Sciences, 10(6), 1-9.

DiYanni, R. (2007). Literature, reading fiction, poetry, and drama (Ashford Custom 6th

Dwiyanti, N. (2016). The Analysis of Meaning in Robert Frost Poems. M A Thesis. English Department Faculty of Letters. Warmadewa University

ed.). New York: McGraw-Hill.

Elaf, B.S, Alakrash, A.M. (2020). An analysis of impoliteness strategies performed by Donald Trump tweets addressing the middle east countries.Global journal of Social Science and Humanities,1, 66-74.

English Department.

Kehar, T. A. (2018). "Semantic Analysis of Ode to Death Poem". International Journal of English Literature and Culture.http://www.academicresearchjournals.org/IJELC/PDF/2018/December/Kehar.pdf

Khalid, J. (2015). Poetic Imagry and Symbosim in Nizar Qabbani's Elegy Balqis. INSTITUTIONEN FÖR SPRÅK OCH LITTERATURER.

Kineavy, J. (1971). A Theory of Discourse. Englewood Cliffs. N. J: Prentice Hall.

Kristeva J. (1984). Revolution in Poetic Language. New York, NY: Columbia University Press.

Mahmood, R. Jamil, A. (2015). A Stylistic Analysis of the Holly Thursday I by William Blake. International Journal of English Language and Linguistics Research Vol.3, No.6, pp.46-52, September 2015. http://www.eajournals.org/wp-content/uploads/Stylistics-Analysis-of-Holly-Thursday-I-by-William-

Blake.pdf (1990)

Mikics, D. (2007). A New Handbook of Literary Terms. London: Yale University Press.

Nursyal. (2009). Imagery and Figurative Language Analysis in Two Poems by Robert Frost. MA Thesis: Universit As Islam Negeri : Syarif Hidayatullah Jakarta.

Poem Hunter. (2020). Badr Shakir al-Sayyab - Badr Shakir al-Sayyab Biography. https://www.poemhunter.com/badr-shakir-al-sayyab/biography/

Poetry Foundation. (2020). T.S. Eliot . 61 West Superior Street, Chicago, IL 60654.

https://www.poetryfoundation.org/poets/t-s-eliot

R, Umagandhi and M, Vinothini. (2017). Leech's Seven Types of Meaning in Semantics. International Journal of Multidisciplinary Research and Development. Volume 4; Issue 3; March 2017; Page No. 71-72

Leech, G. N. (1981). Semantics: The Study of Meaning. Penguin Books.

Tariq, M . (2018). Style, stylistics and stylistic analysis: A re-evaluation of the modern-day rhetorics of literary discourse. International Journal of English Research. Volume 4; Issue 2; March 2018; Page No. 46-50

Ullman, S. (1971). Meaning and Style. Oxford : Basil Blackwell.

Wales, K. (2011). A Dictionary of Stylistics. $3^{\text {rd }}$ Edition. Routlege ( Taylor and Francis Group) : London and New York. 